\title{
社会的相互作用を考慮した CEV普及シミュレーション
}

\author{
奥嶋 政嗣 1 - 石井 亜也加2 \\ 1正会員 徳島大学准教授 大学院ソシオテクノサイエンス研究部（テ770-8506 徳島市南常三島町2-1） \\ E-mail: okushima.masashi@tokushima-u.ac.jp \\ 2学生会員 徳島大学学生 大学院先端技術科学教育部建設創造システム工学コース
}

\begin{abstract}
温室効果ガス排出削減に向けて, 運輸部門においてもモーダルシフトの促進に加えて, EV・PHVとい ったクリーンエネルギー車両 $(\mathrm{CEV})$ への転換を促進することも必要である。ここでCEVの普及に関して は，社会的相互作用が影響することが考えられる。本研究では，局所的相互作用（同調効果）を考慮して， CEV普及促進策を検討するためのマルチエージェントモデルを構成する。ここで，エコカー購入意向に関 するアンケート調査結果を用いて，環境意識と局所的相互作用を考慮してCEV保有意向モデルを記述する. また, 燃費と車両走行距離の関係についてもモデル化し，二酸化炭素排出量を算出可能とする. このシミ ュレータを用いて各種シナリオに関して, CEVの普及状況を比較する.これより，CEV普及に関して社会 的相互作用の影響を把握できる.
\end{abstract}

Key Words : multi agent simulation, local interaction, social conformity, small world network, clean energy vehicle

\section{1. はじめに}

温室効果ガス排出による地球温暖化問題が深刻化して おり，持続可能な低炭素型社会を早期に実現する必要が ある。運輸部門においても，過度な自動車利用の抑制の 取り組みがなされてきた1). しかしながら, 地方都市圈 では公共交通機関などのサービス水準が低く，自動車依 存型社会となっており，他の交通手段への転換は実現が 容易ではない.このため，モーダルシフトの促進に加え て, 電気自動車 $(\mathrm{EV})$ ・プラグインハイブリッド自動 車 (PHV) のような地球環境への負荷が低いクリーンエ ネルギー車両（CEV:clean energy vehicle）への転換を促進 することも必要である.

マーケティングリサーチの分野では，CEVのような新 製品の普及に関して，消費者はリスク低減のために情報 探索行動をとり，他の消費者の購買状況に影響を受ける ことが指摘されている2．（代表的な新製品の普及モデル としてはBassモデルを挙げることができ, 購買周期の長 い而讨消費財の新規需要の分析に適しているとされてい る3). Bassモデルでは，他者の影響を受けない消費者 (イノベーター）と他者の影響を受ける消費者（イミテ 一ター）を想定し，新製品の市場導入から成長期までの 普及構造が簡潔に表現されている.
さらに最近では，たとえば，家電製品である大型TV の普及予測に関して, Bassモデルとコンジョイント分析 を組み合わせたモデルが提案されている4).また，温暖 化対策のための環境製品の普及に関して, Bassモデル, 消費者選好モデル，学習曲線モデルを統合した評価モデ ルも構築されている5). エコカーの普及に関しても， Bassモデルとコンジョイント分析を組み合わせたモデル が適用されているの。 ささらにEVの普及に関しても，EV普 及促進に関するWebアンケート調査結果に基づいて，社 会的同調効果がEV保有意向に影響することが明らかに されている7).ここでの社会的同調効果とは, 社会全体 でのEVの購入シェアの向上が，各個人のEV保有意向を 高めることを指す。このように，家電製品あるいは自動 車などの新製品の普及に関して，いくつかの既往研究に おいて社会的相互作用を考慮した普及シミュレーション が構築されている. また, 本研究で対象とするCEVの普 及に関しても，社会的同調性を考慮した分析がなされて いる.これらの既往研究においては，社会全体の普及率 が個々の消費者に影響を与える構造となっている.

しかしながら，実際の消費行動でみられるクチコミな どの効果あるいは地域性の発現といった現象を適切に表 現するためには，社会的ネットワークにおける局所的相 互作用を想定したモデル構造が要求される.このような 
認識に基づいて，家電製品の普及では，家庭用VTRの普 及に関してマルチエージェントモデルによる人工市場ア プローチが適用されている おける局所的相互作用の影響の重要性が指摘されている また，社会的ネットワーク研究で提案されている典型的 なネットワーク構造を対象に，消費者間の相互作用ネッ トワークを組み込んだ製品市場のモデル化が行われる9 など，新製品の普及に関して，いくつかのマルチエージ エントモデルの構築が行われている. したがって, 本研 究においても，社会的ネットワークにおける局所的相互 作用を組み込んだマルチエージェントモデルによるアプ ローチを採用し，CEVの普及分析に適用することとする.

一方，CEV保有意向に関しては，環境意識が影響する ものと考えられる. また，筆者らは地球環境問題に関わ る環境意識には，親近者の環境意識が影響し，局所的相 互作用が働くことを検証している ${ }^{10)}$. したがって，CEV の普及に関しては，社会的同調効果だけでなく環境意識 とその局所的相互作用も考慮する必要があると考えられ る.ここで，筆者らは通勤交通手段転換促進策を検討す るために，環境意識に関する局所的相互作用を表現した マルチェージェントシミュレーションモデル（MAS）

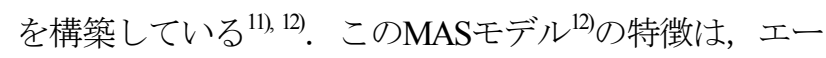
ジェント間の局所的相互作用の表現のために，スモール ワールドネットワークモデル ${ }^{13)} に よ り$ 社会的ネットワー クを記述していることである。このMASモデルの枠組 みを利用することで，環境意識に関する局所的相互作用 が社会全体に及ぼす影響を捉えることが可能となる.

そこで本研究では, 既存研究 ${ }^{12)}$ こおけるMASモデルを 参考として, CEVの保有に関する社会的同調効果を局所 的相互作用として表現し，CEV普及促進策を検討するた めのマルチエージェントシミュレーションモデル

（CEVMAS）を構成する.ここで，CEV保有意向に関す るアンケート調査結果を用いて，CEV保有意向モデルを 構築する. これにより，社会的相互作用について考慮が 必要ない場合に関しては，基本的な推計精度が確保され る.ここで環境意識だけでなく, 社会的同調効果として の局所的相互作用の影響を把握する. このような枠組み で構成したシミュレータCEVMASを用いて，各種のシ ナリオに関して，人工社会におけるCEVの普及促進状況 を観察する.このように，CEVの普及過程において，環 境意識および社会的同調性の両方について，社会的市ッ トワークにおける局所的相互作用の影響を考慮している 点に特徵がある．ただし，環境意識の変遷および社会的 ネットワークについては，精密な統計モデルを構築する ものではない.したがって，構築するCEVMASによる シミュレーション結果は，現実のCEV普及率を精緻に表 すことはできないものの，CEVの普及過程の概略を把握 することが可能であり，環境意識および局所的相互作用
の影響の程度を表すものとなる.

\section{CEVの保有意向に関する分析}

ここでは，CEV保有意向アンケート調査結果データを 用いて, 次回の購入車両に関して, EVあるいはPHVを 候補とする可能性について分析する. また，局所的相互 作用および経済的インセンティブがCEVの保有意向に与 える影響について分析を行う。

\section{(1) CEV保有意向調査アンケートの概要}

現状でのCEV保有意向を把握するために，徳島県民を 対象にWebアンケート調査を実施している ${ }^{14)}$. アンケー 卜調査期間は，大手メーカーによるEVの販売時期及び PHVの販売時期よりも早い2011年10月21日〜28日および 11月 15日〜24日である. 有効サンプルとして464サンプ ルが得られている. 主な調査項目は世帯属性, 現状の保 有車両, 次回保有意向車両である. 次回保有意向車両に ついては，CEVを含む車種，車型，購入時期，購入希望 価格の4項目について回答が得られている.また, CEV のデザインおよびメーカーなどが多様化した前提で，仕 様を具体化した質問を行い，CEVの選択傾向が把握され ている.さらに，局所的相互作用として，親近者がCEV を保有している場合の選択および，社会的同調効果とし て，社会全般での保有率が与えられた場合の選択につい て回答が得られている。

\section{（2）次期車両保有意向に関する整理}

ここでは，世帯での自動車の購入予定時期について整 理した後，購入予定車両の車型およひ購入予定価格につ いて分析する. さらに，これらを踏まえてCEVの保有可 能性について分析する.

\section{a) 購入予定時期}

世帯での自動車の購入予定について，買い替えおよび 新規購入（買い足しを含む）の時期に関する回答の割合 を整理して，図-1に示す。ここでは，買い換えについて は自動車保有世帯の443サンプル，新規購入については 全被験者の464サンプルを対象として，それぞれについ て回答を得ている.

買い換えについては，時期を想定しているのは自動車 保有世帯の $54 \%$ であり，5年以内での更新可能性を検討 している世帯は35\%であった。このことから，地球環境 負荷の低い自動車の普及期間に関しては，たとえ販売さ れる車両のシェアが大幅に増加したとしても，5年程度 の短期間では十分ではないことが明確である.

一方，新規購入に関しては，時期を想定しているのは $11 \%$ あ゙あた。また5年以内での新規購入可能性を検討 


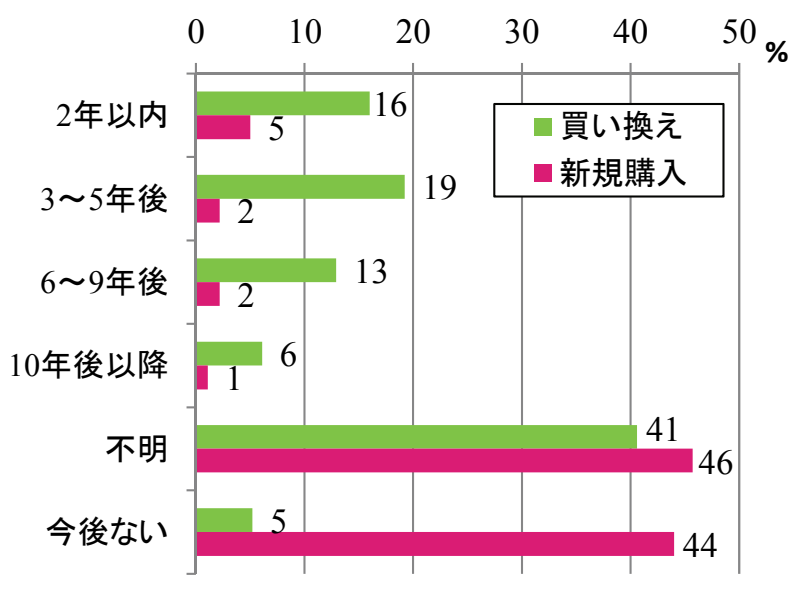

図-1 自動車購入予定時期

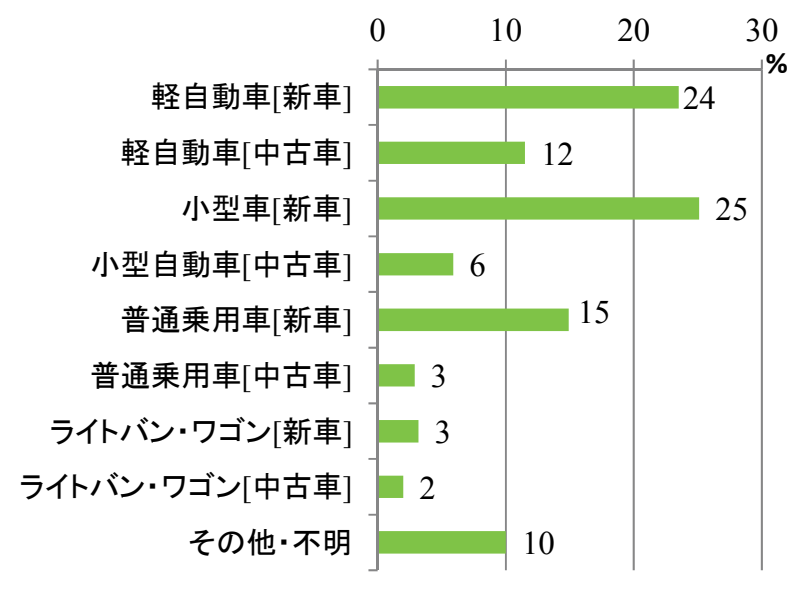

図-2 購入候補車型

している世帯は7\%であった。買い換えおよび新規購入 の可能性について両方に「今後一切ない」と回答した割 合は $5 \%$ であり，大多数の世帯では今後も自動車の購入 可能性があることがわかる.

以下では，買い換えおよび新規購入の可能性のないサ ンプルを除いた442サンプルを対象に，次回の購入車両 についての分析を行う.

\section{b) 次期購入予定車両の傾向}

次回に世帯で購入する自動車について，車型および新 車・中古車を区分して, 購入の可能性の高い上位3位ま での回答を得ている. ここでは，購入予定車両候補の第 1位の選択割合を算出した結果を図-2に示す。

購入予定車両候補の第1位としては，新車の割合が $67 \%$ と高いものの, 中古車の購入意向も $22 \%$ あ, 地球 環境負荷の少ない車両の普及検討では, 中古車の存在も 無視できないものと考えられる. 一方，車型に関しては， 軽自動車および小型乗用車について, 現状の保有割合と 同程度の購入意向がみられる。しかしながら，普通乗用 車の購入意向については，現状の保有割合よりも減少す る傾向がみられる。

つぎに，購入予定車両の車両価格に関してみてみると， 100万〜200万円が全体の45\%を占め，300万円以上の回答 は6\%と非常に少ない. したがって，現在販売されてい るEVおよびPHVに関しては，販売価格の観点からは購 入予定者が限定されることになる.

\section{c) CEVの保有可能性}

ここでは，CEVの保有可能性に関して整理する．次回 に世帯で購入する自動車の車種（動力形式）について購 入の可能性の高い上位3位までの回答が得られている. なお，候補として第2位，第3位が特にない場合は「不明」 を選択するように指示されている，車種別に，回答順位 の割合を算出した結果を図-3に示す.

第1位に選択された車種の割合についてみると，低然 費型ガソリンエンジン自動車を候補とする割合が $32 \%$ と

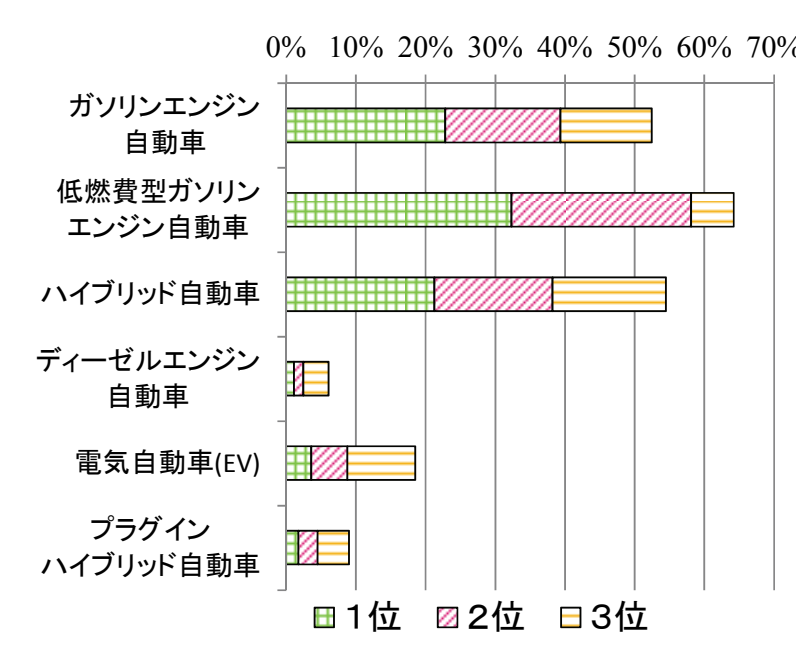

図-3 購入候補車種

高く，ついで（非低然費型）ガソリンエンジン自動車お よびHVの選択意向が高いことがわかる.

低然費型ガソリンエンジン自動車については，アンケ 一ト実施時に然費が $25 \mathrm{~km} / \mathrm{L}$ 以上であることを明示して 提示している. 現状の保有車両と比較して，低然費型力゙ ソリンエンジン自動車およびHVのシェアが大幅に増加 する可能性が伺える。これは燃費を考慮する利用者層が 拡大しつつあることを示していると考えられる. 一方で, 低然費型でないガソリンエンジン自動車の購入意向につ いても，依然として一定以上の割合で存在していること にも留意が必要である.

一方，EVあるいはPHVを候補として第1位に挙げる被 験者の割合はあわせて $6 \%$ であり，少数であった。なお 「プラグインハイブリッド自動車（PHV）とは，家庭な どで充電が可能なハイブリッド自動車で，主にモーター で走行する車両である」ことを被験者に提示されている. ここで，第1位から第3位までに，EVを挙げている割合 は19\%，PHVを挙げている割合は9\%である。EVおよび PHVの両方を挙げている6\%を考慮すると，EVあるいは 
PHVのいずれかを候補に挙げている割合は全体の $22 \%$ ある. 以上のようなことから，当面は低燃費型ガソリン エンジン自動車およびHVの普及が先行し，EVあるいは PHVの普及はその後の状況次第であると考えられる.

つぎに, EV あるいはPHVのデザインおよびメーカー などが多様化した前提で，仕様を具体化した質問を行い， 選択傾向が把握されている. 被験者に対して, 次回の購 入を検討した車両のなかで, 最も購入可能性の高い仕様 の車両と比較して, EV あるいはPHVを購入するかの選 択について質問されている．具体的なEV・PHVの車両 条件は以下の項目を提示している.

・ハイブリッド自動車を除く（電気自動車あるいはプラ グインハイブリッド自動車)

・温室効果ガス排出量 : ゼロ（モーターでの走行中には 二酸化炭素を発生しない)

-車両購入価格 : 現行補助金（上限100万円）を差し引 いて, 比較車両より 100 万円程度高額

・家庭でのフル充電までの時間 : 8時間程度

-平均走行コスト : 1 円 $/ \mathrm{km}$ 程度（通常のガソリン車 : 10 円 $/ \mathrm{km}$ 程度, その他の低燃費車両 : 6 円 $/ \mathrm{km}$ 程度)

・モーターでの航続可能距離 : $200 \mathrm{~km}$ 程度

・デザイン・定員・メーカーなど : 比較する車両と同一 これは，デザイン・定員・メーカーなどの条件を除い ては，現在販売されているEVの仕様を提示したもので ある．以上のような条件設定に対して得られた回答では, $\mathrm{EVが17 \% ，PHVが} 25 \%$ となっており, 次回の購入予定車 両の候補として第1位に選択された車種の割合と比較す ると，大幅に高いことがわかる。したがって，EV ある いはPHVのデザインおよびメーカーなどが多様化し，従 来の車両と燃費性能と車両価格のみで比較できるように なった場合には，シェアが拡大寸る可能性が伺える。ま た, 選択対象の候補となった場合には, 一定以上のシェ アが確保できる可能性があることが示唆される.

\section{（3） CEV保有への社会的相互作用による影響}

ここでは, CEV保有意向への社会的相互作用による影 響について分析する. 社会的相互作用として, 親近者 （友人・同僚など）からの影響（局所的相互作用）およ び社会全体での市場シェアの影響（社会的同調効果）に ついて検討する.

まず，局所的相互作用に関して，CEV保有意向への影 響を分析する. アンケート調查では, 被験者の一番身近 な人（友人・同僚など）を1人想定し，その親近者が CEVを保有している場合について，CEVを購入する可能 性について質問している. 次回の購入予定車両の候補と してCEVが含まれているかでCEV保有可能性を区分して, 親近者のCEV保有の局所的影響によるCEV購入可能性の 回答割合を算出した結果を図-4に示す.

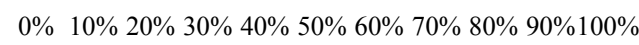

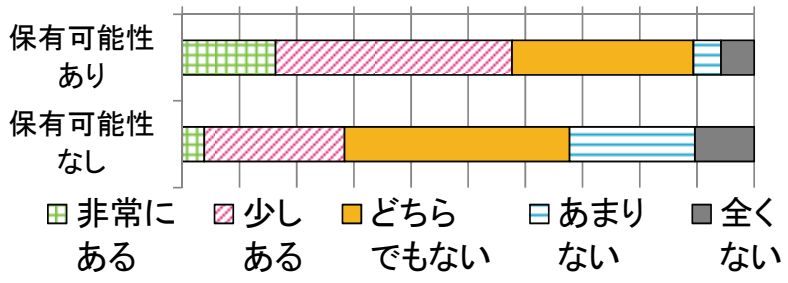

図-4 CEV保有可能性への局所的影響

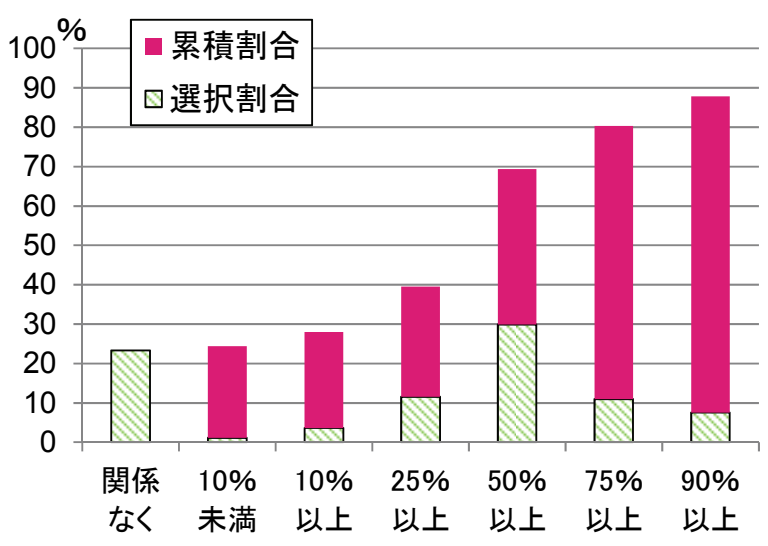

図-5 市場シェアとCEV保有可能性の関係

$\mathrm{CEV}$ 保有可能性がない被験者（購入予定車両の候補外 である被験者）においても，親近者の影響により購入可 能性が「非常にある」または「少しある」との回答が合 わせて28\%である.したがって，CEV保有意向に関して， 親近者の影響（局所的相互作用）を考慮する必要性が示 唆された.

つぎに，社会的同調効果に関して，CEV保有一の影響 を分析する. アンケート調査では, CEVを保有する自動 車保有者の割合を選択肢として示し，CEVの保有割合が 何\%以上であれば次回にCEVを購入するかについて質問 している. 市場シェア（CEVの保有割合）に対応した $\mathrm{CEV}$ 保有意向を示した回答の割合を図-5に示す.

市場シェアが90\%以上の場合を除いては，市場シェア よりも購入意向を示寸累積割合が高い結果となっている. したがって, 市場シェアは拡大する方向で推移する可能 性が高いことが考えられる．特に，50\%以上の保有割合 の場合には，購入意向は70\%に達する．このように，社 会的同調効果が強いことがわかる.

\section{CEV普及MAシミュレーションの構成}

ここでは，既存研究でのMASモデル212を参考としなが ら，CEV普及促進策の検討のためのマルチェージェント シミュレーションモデルCEVMASを構成する. 


\section{(1) MASモデルの構成}

本研究でのMASモデル全体の基本フローを図-6に示寸。 「車種決定プロセス」，「排出量算定プロセス」に加え て，「時間進行管理プロセス」を含めた構成としている。

「車種決定プロセス」では, エージェントの車両購入 時点での車種選択の意思決定を記述する．このとき，世 帯属性および保有車両だけでなく，環境意識，社会的同 調，局所的相互作用を考慮する. 既存研究 ${ }^{12)}$ 参考とし た「環境意識モデル」では，自己の保有車両の燃費に社 会全体の「二酸化炭素排出量」を含めて交通環境を評価 すると仮定する．一方，「局所的相互作用モデル」では， 社会的ネットワークにおいて関連するエージェントの保 有車種により，CEV 保有意向に影響する相互作用効果 を記述する．このとき，既存研究 ${ }^{12)}$ を参考として社会的 ネットワークをスモールワールドネットワークモデルに より表現する．車種選択に関しては，これらの要素を考 慮して，「CEV 保有意向モデル」では CEV 保有意向の 程度を測定し，「車種選択モデル」により保有車種を確 率的に決定する 2 段階のモデル構造としている.

「排出量算定プロセス」では，保有車両の利用によ る二酸化炭素排出量を推計する. このとき，保有車両の 燃費および走行距離を考慮する。「燃費モデル」では, 世帯属性と保有車両に対応した確率分布（ワイブル分布） に基づいて，確率的に保有車両の燃費を決定する。「走 行距離モデル」についても同様に，世帯属性と保有車両 に対応した確率分布に基づいて，確率的に平日休日別の 1日の総走行距離を決定寸る.これらの要素に基づいて, 「排出量モデル」ではエージェントの保有車両利用によ る二酸化炭素排出量を推計する。この個々のエージェン 卜の排出量を総和して，社会全体での二酸化炭素排出量 を算定する。

「時間進行管理プロセス」では，時間の進行とエージ エントの車両購入イベントを管理する。「車両購入時期 決定モデル」では，世帯属性，保有車両および走行距離 に対応した確率分布に基づいて，確率的に車両購入時期 を決定する．この各エージェントの車両購入イベントの 生起により，当該エージェントにおける「車種決定プロ セス」および「排出量推計プロセス」が実行される。こ のように，人工社会の状況を順次更新することで，シミ ュレーションを実行し，CEVの普及状況および二酸化炭 素排出量の推移を観察する.

\section{（2）時間進行管理プロセス}

時間進行管理プロセスでは，車両購入時期決定モデル により確率的に車両購入時期を決定するエージェントの 車両購入イベントの生起を実行する。ここでは, 次回の 車两購入までの期間を確率的に決定することを目的とし て，CEV保有意向に関するアンケート調査結果を用いて，

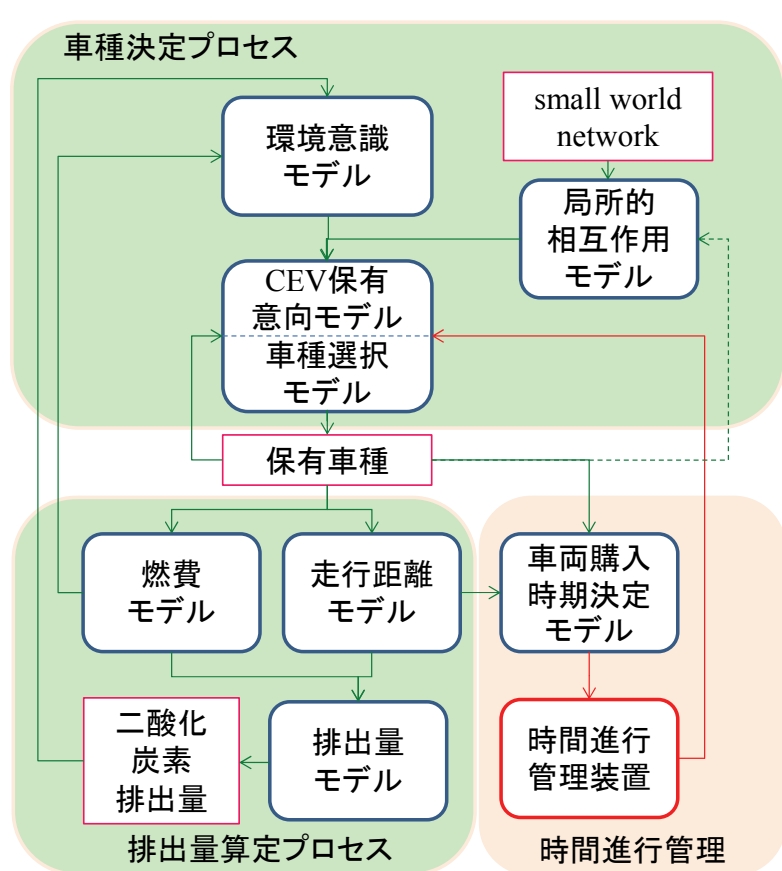

図-6 マルチエージェントシミュレーションの全体フロー

表-1 車両購入時期決定モデルのパラメータ推定結果

\begin{tabular}{|l|r|r|r|}
\hline \multicolumn{1}{|c|}{ 要因名称 } & \multicolumn{1}{c|}{ 係数 } & \multicolumn{1}{c|}{$t$ 值 } & 平均値 \\
\hline 定数項 & 1.50 & 29.7 & 1.00 \\
\hline 幼児·乳児ダミー & 0.29 & 2.43 & 0.17 \\
\hline 高収入ダミー & -1.05 & -4.50 & 0.04 \\
\hline 形状パラメータ $p$ & 1.43 & -7.04 & - \\
\hline
\end{tabular}

車両購入時期決定モデルを構築する. 各種要因 $x_{k}$ の影響 (係数パラメータ $\left.\beta_{k}\right)$ も考慮できるパラメトリックな加 速八ザードモデル ${ }^{15)}$ の枠組を用いる。ここで，車両購入 時期の確率分布としてワイブル分布を仮定すると，次回 車両購入までの期間 $s$ (年)の累積確率 $F(s \mid x)$ は, 式(1)のよ うに記述できる.

$$
F(s \mid x)=1-\exp \left[-s^{p} \cdot \exp \left(\sum-p \beta_{k} x_{k}\right)\right]
$$

車両購入時期について回答のあった254サンプルを対 象として分析する. 車両購入時期に関しての基本統計量 は，平均值4.2年，中央值4.0年，標準偏差3.0年となって いる．統計的に有意でない要因は順次削除していくこと により, 最終的に得られた車两購入時期決定モデルのパ ラメータ推定結果を表-1 に示す. ダミー变数に関して の平均值は，ダミ一反応割合を表している．次回車両購 入までの期間について，世帯構成員に幼児・乳児が含ま れる場合には長く，高収入（世帯年収 1500 万円以上）の 世帯では短いことがわかる，モデルの全体では，最大対 数尤度-592であり，モデルの適合度について $\chi^{2}$ 值 は17.4 となり， $\chi^{2}$ 検定により有意水淮 $5 \%$ で実績值との靟離はな いといえる. 
マルチエージェントシミュレーションでは，この車両 購入時期決定モデルを用いて確率的に次回車両購入時期 を決定することとする. このため，決定された車両購入 時期になったエージェントのみが車種決定プロセスにし たがって車種決定を行うこととし，それ以外のエージェ ントに関しては各時点における保有車両の変更はないも のとする.

\section{(3) 排出量算定プロセス}

排出量算定プロセスでは，「燃費モデル」，「走行距 離モデル」および「排出量モデル」により個々のエージ エントについて保有車両の利用による二酸化炭素排出量 を推計し, 社会全体での二酸化炭素排出量を算定する.

ここでは，これらのモデルの具体的な構成を行うことと する.

\section{a) 燃費モデル}

現在の保有車両の特性を表す指標として然費の分布に ついて分析し, 保有車両の燃費モデルを構築する.ここ で然費のヒストグラムの分布形状からワイブル分布を採 用する ${ }^{14)}$. 各種要因 $x_{k}$ の影響（係数パラメータ $\beta_{k}$ ）も考 慮して, 前述の車両購入時期決定モデルと同様に, 式 (2)に示すパラメトリックな加速ハザードモデル ${ }^{15)}$ の枠組 を用いて燃費 $y$ の累積確率 $F(y \mid x)$ が分析されている.

$$
F(y \mid x)=1-\exp \left[-y^{p} \cdot \exp \left(\sum-p \beta_{k} x_{k}\right)\right]
$$

燃費について回答のあった267サンプルを対象として 分析する。燃費に関しての基本統計量は，平均值 $12.9 \mathrm{~km} / \mathrm{L}$ ，中央值 $12.0 \mathrm{~km} / \mathrm{L}$ ，標準偏差 $4.5 \mathrm{~km} / \mathrm{L}$ とってい る. 統計的に有意でない要因は順次削除していくことに より，最終的に得られた然費モデルのパラメータ推定結 果を表-2に示す. ダミ一変数に関しての平均值は, ダミ 一反応割合を表している，車種については「HV」の然 費が高く，車型では「小型乗用車」よりも「軽自動車」 の然費が高いことを示す妥当な結果が得られている。ま た，30才未満および50〜64才の女性がメインドライバー である場合および，1日あたりの車両走行距離が長い場 合には，然費の高い車両を保有・利用する傾向がうかが える.このように，車型，メインドライバー属性および 車両走行距離などの要因と現状保有車両の環境性能との 関係が統計的に示されている. モデルの全体では，最大 対数尤度-712であり，モデルの適合度について $x$ 值 は 129.6 となり， $\chi^{2}$ 検定により有意水準 $5 \%$ で実績值との乘 離はないといえる.この然費モデルを，CEV以外の保有 車両の燃費を確率的に決定するために適用する.

\section{b) 走行距離モデル}

保有車両利用による1日における走行距離を確率的に 決定することを目的として，CEV保有意向に関するアン ケート調査結果を用いて, 走行距離モデルを構築する.
表-2 燃費モデルのパラメータ推定結果

\begin{tabular}{|l|r|r|r|}
\hline \multicolumn{1}{|c|}{ 要因名称 } & \multicolumn{1}{c|}{ 係数 } & \multicolumn{1}{c|}{$t$ 值 } & 平均値 \\
\hline 定数項 & 2.31 & 66.2 & 1.00 \\
\hline 軽自動車ダミー & 0.431 & 10.4 & 0.28 \\
\hline 小型乗用車ダミ一 & 0.305 & 7.82 & 0.37 \\
\hline HVダミー & 0.750 & 6.81 & 0.02 \\
\hline メインドライバー30才未満女性 & 0.304 & 3.43 & 0.03 \\
\hline メインドライバー50〜64才女性 & 0.273 & 4.77 & 0.09 \\
\hline 車両走行距離 $(\mathrm{km} /$ 日) & 0.002 & 2.04 & 15.6 \\
\hline 形状パラメータ $p$ & 3.84 & -30.0 & - \\
\hline
\end{tabular}

表-3 走行距離モデルのパラメータ推定結果

\begin{tabular}{|l|r|r|}
\hline \multicolumn{1}{|c|}{ 要因名称 } & \multicolumn{1}{c|}{ 係数 } & \multicolumn{1}{c|}{$t$ 值 } \\
\hline 定数項 & 2.79 & 57.2 \\
\hline 形状パラメータ $p$ & 1.10 & -2.44 \\
\hline
\end{tabular}

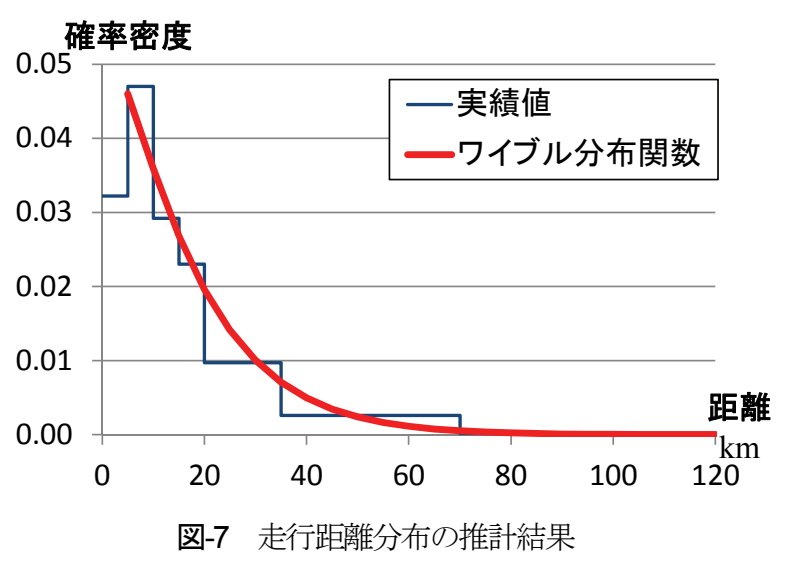

各種要因 $x_{k}$ の影響（係数パラメータ $\beta_{k}$ ） も考慮して, 前述の車両購入時期決定モデルおよび然費モデルと同様 に，式(3)に示すパラメトリックな加速ハザードモデル ${ }^{15}$ の枠組を用いて走行距離 $d$ の累積確率 $F(d x)$ を分析する.

$$
F(d \mid x)=1-\exp \left[-d^{p} \cdot \exp \left(\sum-p \beta_{k} x_{k}\right)\right\rfloor
$$

走行距離について回答のあつた390サンプルを対象とし て分析する. 日走行距離に関しての基本統計量は，平均 值 $15.6 \mathrm{~km}$, 中央值 $12.0 \mathrm{~km}$, 標準偏差 $15.1 \mathrm{~km}$ となっている. 統計的に有意でない要因は順次削除していくことにより， 最終的に得られた走行距離モデルのパラメータ推定結果 を表-3に示す.ここでは形状パラメータおよび定数項を 除くすべての要因が有意とならなかった. したがって, 走行距離モデルはすべてのエージェントに共通の単純な ワイブル分布関数で表される. このとき, 最大対数尤度 -1459である. なお，誤差項に正規分布を仮定した線形 回帰モデル（重回帰モデル）を適用した場合においても， 統計的に有意な説明変数を得ることはできていない.ま た，重回帰モデルの決定係数 $R^{2}$ 值は0.014となり，モデル の適合度は低い. 一方, ワイブル分布関数を適用した場 合について，実績值の確率密度と推定されたワイブル分 
布関数を合わせて図-7に示す. $5 \mathrm{~km}$ 以上の範囲では, 概 放実績值に近似した分布を表現できていることがわかる。 分布の適合度について $\chi^{2}$ 值 は13.7となり， $\chi^{2}$ 検定により 有意水準 $5 \%$ で実績值との乘離はないといえる.

\section{c) 排出量モデル}

排出量モデルでは，「走行距離モデル」により決定さ れた走行距離 $d$ に, 単位走行距離あたりの二酸化炭素量 の排出原単位efを乗じて, 個々のエージェントの二酸化 炭素排出量 $c e$ を式(4)のように算定する.

$$
c e=e f \cdot d
$$

ここで，二酸化炭素量の排出原単位efについては, CEVおよびCEV以外の車両に区分して算定する．CEVで は，国内大手メーカーにより市販されている電気自動車 の単位走行距離あたりの二酸化炭素量の公表值 $0.048 \mathrm{~kg} / \mathrm{km}$ を排出原単位efとする. 一方で, CEV以外の車 両では, 単位距離 $1 \mathrm{~km} の$ 走行により排出される二酸化炭 素排出量原単位 ef は，ガソリン $1 \mathrm{~L} の$ 消費による二酸化 炭素排出量 $e f_{0}(=2.3 \mathrm{~kg} / \mathrm{L})^{10)}$ と「燃費モデル」により決定さ れた保有車両の燃費 $y$ にり式(5)のように算定する.

$$
e f=e f_{0} / y
$$

社会全体での二酸化炭素排出量は，すべての自動車利 用エージェントについて, 二酸化炭素排出量 $c e$ を集計 することで算定できる．また，全体での二酸化炭素排出 量と二酸化炭素排出枠 $c e_{\text {max }}$ の差から, 超過排出量を算 定し，これをオフセットするための一人あたりの平均費 用 $a c$ を式(6)で求める.

$$
a c=\frac{p}{n}\left(\sum_{i} c e_{[i]}-c e_{\max }\right)
$$

なお，全体での二酸化炭素排出量が二酸化炭素排出枠 よりも少ない場合には，平均費用 $a c$ は発生しないもの とする. ただし，ここでは二酸化炭素排出枠 $c e_{\max }$ を推計 開始年次において5.0[ton-CO $/$ day] としている。.また，二 酸化炭素排出枠は徐々に減少寸ることとし，16年後には 50\%減少することとして設定する.

また，既存研究 ${ }^{12)}$ における通勤交通手段転換に関わる MAシミュレーションと同様に, 二酸化炭素排出権の平 均取引価格 $p$ は排出量に比例して式(7)のように設定され ることとする．ここで環境省JVETSによる二酸化炭素排 出権の平均取引価格を参考に, 二酸化炭素の単位排出削 減費用 $p_{0}$ を1,212円 $/$ ton- $\mathrm{CO}_{2}$ と設定する ${ }^{17)}$.

$$
p=\frac{p_{0}}{c e_{\max }} \sum c e_{[i]}
$$

以上のように, $\mathrm{CEV}$ 普及促進策検討のためのマルチエ ージェントシミュレーションの基本的な構成を行った.

\section{(4) 車種決定プロセス}

本研究では，保有車種決定過程に関して，環境意識，

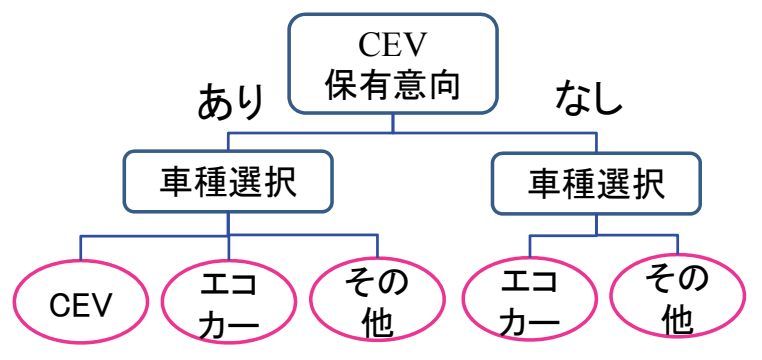

図-8 車種選択についての意思決定構造の仮定

局所的相互作用を考慮して, 車両購入時点での車種選択 を確率的に表現する。このため，車種決定プロセスを 「CEV保有意向モデル」,「車種選択モデル」に加えて, 「環境意識モデル」および「局所的相互作用モデル」で 構成する.

\section{a）車種選択に関する意思決定構造の仮定}

車種選択に関しては，図-8に示すような2段階のモデ ル構造としている，上位では「CEV保有意向モデル」に よりCEV保有意向の程度を測定する。下位ではCEV保有 意向の有無に対応して，それぞれの区分に応じた「車種 選択モデル」により保有車種を確率的に決定する構造と している。本研究では，CEVはEVあるいはPHVのいず れかの車種選択を表し, エコカーはHVあるいは燃費 $25 \mathrm{~km} / \mathrm{L}$ 以上の低燃費型ガソリンエンジン自動車のいずれ かの車種選択を表すこととする.

b) CEV保有意向モデル

ここでは，エコカー保有意向アンケート調査結果のデ ータを用いて, 非集計二項ロジットモデルにより CEV 保有意向モデルの構築を行う. 被説明変数となる CEV 保有意向の有無に関しては，次回保有車両候補に関する 質問への回答に加えて, 局所的相互作用の影響への回答 も合わせて分析することとする．次回保有車両候補に関 する質問への回答については, 候補車種上位 3 位までに $\mathrm{CEV}$ を挙げたサンプルについて「CEV 保有意向」を

「有り」とする. 一方, 局所的相互作用の影響への回答 については，「非常にある」または「少しある」との回 答を「CEV 保有意向」を「有り」とする．このように， 442 サンプルの 2 種類の質問への回答として，884 の選 択結果を分析の対象とした. CEV 保有意向者の割合は, 局所的影響がない場合には $22 \%$ であり，局所的影響が ある場合には $35 \%$ である。

CEV保有意向に関わる要因として，世带人数，運転免 許保有者数, 世帯構成属性, 保有車両の車種・車型, メ インドライバー, 次回保有車型, 車両価格, 走行距離, 利用頻度, 地球温暖化一の関心，車両排出ガスの削減必 要性の認識および局所的影響を検討した. 各説明変数は カテゴリー化によりダミー変数とし，「CEV保有意向あ り」の選択肢固有変数とした．統計的に有意でない要因 は順次削除していくことにより, 最終的に得られたCEV 
保有意向モデルのパラメータ推定結果を表-4に示す．な お，尤度比は 0.201 となり，モデルの適合度は概ね良好 である.

$\mathrm{CEV}$ 保有可能性に関わる要因として,「地球環境問題 への関心」を「高」「普通」「低」の3区分に分類して 分析したところ，「高」および「低」ともに有意となっ ており, 関心の高さに応じて保有可能性が高くなる傾向 があることがわかる．また，多人数世帯では保有可能性 が高い.ささらに局所的相互作用の影響についても有意と なっており, 親近者のCEV保有が影響を与える構造とな っていることがわかる．定数項は負で有意となっており， 全体的には保有意向が少ない傾向が表現されている.

c) 車種選択モデル

ここでは，CEV保有意向の有無に対応して，それぞれ の区分に応じた「車種選択モデル」により保有車種を確 率的に決定するモデルを構築する. 被説明変数として, 次回保有車両候補に関する質問への回答より, 候補車種 第1位とした車種を選択結果とする，車種選択に関わる 要因としては, CEV保有意向に関わる要因として検討し た項目と同一として検討した.

$\mathrm{CEV}$ 保有意向有りの場合の車種選択モデルに関しては, CEV保有意向がある104サンプルを対象に分析する．こ こで車種に関しては「CEV」「エコカー」「その他」の 3種類に区分することとし，マルチロジットモデルを適 用する. CEV保有意向があるサンプルにおけるCEVの選 択割合は23\%であり，エコカーの選択割合は64\%である。 統計的に有意でない要因は順次削除していくことにより, 最終的に得られたCEV保有意向有りの場合の車種選択モ デルのパラメータ推定結果を表-5に示寸. 尤度比は 0.378 となり，モデルの適合度は良好である.

パラメータ推定結果より, 中高年男性がメインドライ バーである場合にエコカーの選択可能性が高く，特に高 齢男性ではCEVの選択可能性が高いことがわかる。また, 自動車排出削減の必要性の認識について，「高」「普通」 「低」の3区分に分類して分析したところ，認識が高い 場合にはCEVの選択可能性が高く, 認識が低い場合には エコカーの選択可能性が低い傾向となること表現されて おり, 自動車排出削減の必要性が車種選択に関わること が統計的に示されている. また，地球環境問題への関心 が高い場合には，非低燃費型ガソリン自動車の選択可能 性が低いこともわかる．自動車排出削減の必要性につい て認識と地球環境問題への関心とは関連性が高いが，モ デルの適合度を高めるため, より尤度が高くなるように, それぞれの選択肢で採用する説明変数を選択している.

1日における走行距離については，連続変数として説 明変数に採用することを試行したが，有意な結果を得る ことができなかった，そこで，距離帯別にダミ一変数と して適用することとした．試行錯誤により，最終的に，
表-4 CEV保有意向モデルのパラメータ推定結果

\begin{tabular}{|l|r|r|r|}
\hline \multicolumn{1}{|c|}{ 要因名称 } & \multicolumn{1}{c|}{ 係数 } & \multicolumn{1}{c|}{ t值 } & 平均値 \\
\hline 定数項 & -1.53 & -7.89 & 1.00 \\
\hline 局所的影響 & 0.62 & 3.98 & 0.50 \\
\hline 多人数世帯 & 0.53 & 2.91 & 0.71 \\
\hline 地球環境関心 : 高 & 0.66 & 3.75 & 0.22 \\
\hline 地球環境関心 : 低 & -1.32 & -5.39 & 0.24 \\
\hline
\end{tabular}

表-5 車種選択モデル（CEVあり）のパラメータ推定結果

\begin{tabular}{|c|l|r|r|r|}
\hline $\begin{array}{c}\text { 選択 } \\
\text { 肢 }\end{array}$ & \multicolumn{1}{|c|}{ 要因名称 } & 係数 & \multicolumn{1}{c|}{$\mathrm{t}$ 値 } & 平均值 \\
\hline \multirow{4}{*}{ CEV } & メイン車両: Lバン & 2.84 & 2.03 & 0.04 \\
\cline { 2 - 5 } & 高齢男性運転 & 2.24 & 2.63 & 0.07 \\
\cline { 2 - 5 } & 排出削減認識: 高 & 1.39 & 2.50 & 0.29 \\
\hline \multirow{3}{*}{$\begin{array}{c}\text { エコ一 } \\
\text { カー }\end{array}$} & 排出削減認識: 低 & -1.33 & -2.01 & 0.18 \\
\cline { 2 - 5 } & 中高年男性運転 & 1.69 & 2.46 & 0.24 \\
\cline { 2 - 5 } & 日走行距離10-35km & 1.05 & 2.00 & 0.39 \\
\cline { 2 - 5 } & 定数項 & 1.38 & 3.48 & 1.00 \\
\hline \multirow{2}{*}{$\begin{array}{c}\text { その } \\
\text { 他 }\end{array}$} & 直近購入予定あり & 2.98 & 3.11 & 0.14 \\
\cline { 2 - 5 } & 地球環境関心: 高 & -2.71 & -2.02 & 0.32 \\
\hline
\end{tabular}

表-6＼cjkstart車種選択モデル（CEVなし）のパラメータ推定結果

\begin{tabular}{|c|r|r|r|}
\hline 要因名称 & \multicolumn{1}{|c|}{ 係数 } & \multicolumn{1}{c|}{$\mathrm{t}$ 値 } & 平均值 \\
\hline メイン車両 : 小型 & 0.84 & 3.71 & 0.29 \\
\hline 排出削減認識: 低 & -1.07 & -4.59 & 0.29 \\
\hline
\end{tabular}

いくつかの区分を統合するなどした結果として，選択肢 エコカーの効用の説明変数に, 日走行距離10-35kmのダ ミ一変数が採用され, 統計的に有意となった. なお, $\mathrm{CEV}$ 保有意向のある被験者について，アンケート調查結 果における日走行距離の割合をみると，10km末満が48\%, 10-35kmが39\%，35km以上が13\%となっている.

一方，直近（2年以内）での自動車購入予定がある場 合には，非低然費型ガソリン自動車の選択可能性が高く， 購入時期も車種選択に影響寸ることがわかった．またエ コカーの定数項が正で有意となっており, CEV保有意向 のある被験者に関してはCEVよりもエコカーの選択傾向 が強いことが表現されている.

つぎに, CEV保有意向無しの場合の車種選択モデルに 関しては，CEV保有意向があるサンプルを除いた338サ ンプルを対象に分析する.ここで車種に関しては「エコ カー」「その他」の2種類に区分することとし, 二項口 ジットモデルを適用する. CEV保有意向がないサンプル におけるエコカーの選択割合は $50 \%$ である. 統計的に有 意でない要因は順次削除していくことにより, 最終的に 得られたCEV保有意向無しの場合の車種選択モデルのパ ラメータ推定結果を表-6に示す。 
パラメータ推定結果より, CEV保有意向がない場合に は，小型自動車が世帯で最もよく利用する車両であれば, エコカーの選択可能性が高いことがわかる. 一方, 自動 車排出削減の必要性について認識が低い場合には，エコ カーの選択可能性が低い傾向となることがわかった.

\section{d) 環境意識モデル}

通勤者エージェントの環境意識更新プロセスは，「交 通環境評価」，「経験的学習による意識変容」，「社会 的同調性更新」および「環境意識更新」により構成する.

「交通環境評価」では，通勤交通手段の効用の差で表 される満足度だけでなく, 社会全体の運輸部門での二酸 化炭素排出削減費用の負担を考慮する.

二酸化炭素排出量に応じた平均オフセット費用 $a c$ の負 担は, エージェントの環境意識 eco に応じた感度 $\rho$ で評 価されるものとする．環境意識とオフセット費用に対す る感度の関係を図-9に示す。ここで環境意識指標は,

「地球環境問題一の関心」の程度に対応して規定し，最 小值 0.0 最大值 1.0 で指標化したものとする.

交通手段の効用差で表される自動車利用の満足度を貨 幣価值換算したものと, エージェントの環境意識 eco に 応じた感度 $\rho$ で評価されるオフセット費用 $a c$ 負担感を 併せて，交通環境評価值 $g$ を式(8)で算定する.

$$
g_{[i]}=\frac{\mathrm{u}_{[i]}^{\mathrm{car}}-\mathrm{u}_{[i]}^{\text {pub }}}{\left|\theta_{\mathrm{tc}}\right|}-\rho_{[i]} \cdot a c
$$

したがって，車両の燃費および走行距離に応じた二酸 化炭素排出量の総和が，二酸化炭素排出削減のための才 フセット費用 $a c$ を通して，交通環境評価值 $g$ に反映され， 環境意識にフィードバックされる構造となっている.

ここで，先行研究12)参考に，交通サービス水準とし て認知所要時間 $p t t$ と所要費用 $t c$ を想定し, 自動車利用 の確定効用 $u^{\mathrm{ar}}$ は式(9)のように記述できるものとする.

$$
\left.\begin{array}{ll}
u_{[i]}^{\mathrm{car}}=\theta_{t t} \cdot p t t_{[\mathrm{i}]}^{\mathrm{car}}+\theta_{c n t} & \text { if } e c o_{[\mathrm{i}]} \leq L_{e c o} \\
u_{[\mathrm{i}]}^{\mathrm{car}}=\theta_{t t} \cdot p t t_{[\mathrm{i}]}^{\mathrm{car}}+\theta_{t c} \cdot t c_{[\mathrm{i}]}^{\mathrm{car}}+\theta_{c n t} & \text { if } e c o_{[\mathrm{i}]}>L_{e c o}
\end{array}\right\}
$$

環境意識の閾值 $L_{\mathrm{eco}}$ を用いて, エージェントの環境意 識が低い場合には, 自動車の所要費用は考慮されないも のと仮定している.

一方，代替交通手段となる公共交通の確定効用 $u^{\mathrm{pub}}$ は 式(10)のように記述できるものとする.

$$
u_{[i]}^{\mathrm{pub}}=\theta_{t t} \cdot p t t_{[i]}^{p u b}+\theta_{t c} \cdot t c_{[i]}^{p u b}+\theta_{e c o} \cdot e c o_{[i]}
$$

先行研究12)では, 徳島市で行われたエコ通勤促進のた めの通勤シャトルバス運行社会実験に関するアンケート 調査結果を用いて, 最尤推定法により二項ロジットモデ ルのパラメータが表-7のように推定されている. なお,

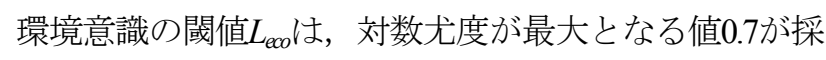
用されており，本研究でもこの值を採用する.

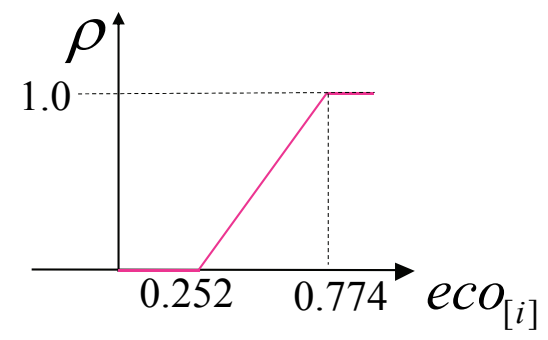

図-9環境意識に対応したオフセット費用に対寸る感度

表-7 交通手段別効用の係数パラメータ推定結果 ${ }^{12)}$

\begin{tabular}{|l|r|r|}
\hline \multicolumn{1}{|c|}{ 選択要因 } & \multicolumn{1}{|c|}{ 推定値 } & \multicolumn{1}{c|}{$\mathrm{t}$-值 } \\
\hline 認知所要時間 $(\mathrm{ptt})[\mathrm{min}]$ & -0.0243 & -4.17 \\
\hline 所要費用 ( tc ) [yen] & -0.00566 & -5.60 \\
\hline 環境意識 ( eco ) & 1.66 & 4.57 \\
\hline 定数項 $(\mathrm{cnt})$ & 1.41 & 4.89 \\
\hline
\end{tabular}

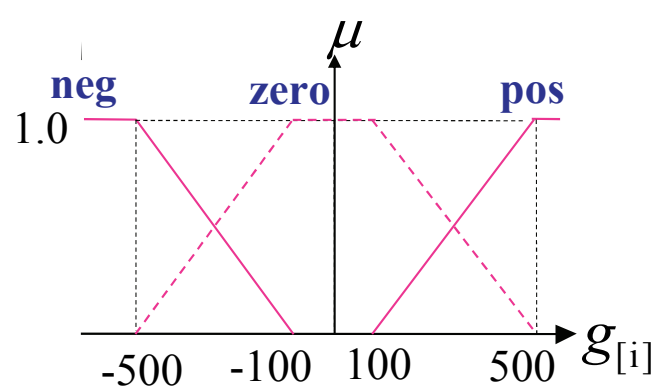

図-10 交通環境評価值のメンバシップ関数

つぎに「経験的学習による意識変容」では，内発的な 環境意識の向上（あるいは減退）入を式(11)で表される ルールによって規定する.

if $g$ is neg and $\Delta g$ is neg then $\lambda$ is pos

if $g$ is pos and $\Delta g$ is pos then $\lambda$ is neg

これらの式は，それぞれ，「交通環境に不満足で，不 満足度が増加していれば，環境意識が向上する」こと， および，「交通環境に満足で, 満足度が増加していれば, 環境意識が減退する」ことを表している.

具体的な算定プロセスでは, 簡略ファジィ推論を利用 する.ここで交通環境評価值のメンバシップ関数は図10に示すように設定することとする.

「社会的同調性更新」では, 関係の深いエージェント から自身の環境意識の向上（あるいは減退）に受ける影 響の程度を，式(12)のように設定する.

ここで列(t)は後述するように，周囲のエージェントか らの影響の強さを表している.

$$
\beta_{[\mathrm{i}]}=w_{0} w_{[\mathrm{i}]}(t)
$$

ここで周囲からの影響の受けや寸さ程度を表す $w_{0}$ は, 個人により相違することが想定されるが，本研究では簡 単のため一定值とし, 既存研究の感度分析の結果を参考 に $w_{0}=0.01$ と設定している. 
「環境意識更新」では，内発的な変化および関係の深 いエージェントからの影響による変化にしたがって徐々 に更新されていくことを仮定し，各サイクルごとに式 (13)のようにエージェントの環境意識ecoを更新寸る．た だし，環境意識ecoの下限値0.0および上限值 1.0 とする.

$$
\operatorname{eco}_{[i]}(t)=e c o_{[i]}(t-1)+\lambda_{[i]}+\beta_{[i]}
$$

以上のように交通環境とエージェントの環境意識の関 係を仮定した.

\section{e) 局所的相互作用モデル}

エージェント間の相互作用を記述するために, 既存研 究 ${ }^{12)}$ と同様にWSモデルにしたがって, small world network モデルにより，概念空間において近接するすべてのエー ジェント間を相互にリンクで結節する．本研究において も, 概念空間でのエージェントの相互作用の影響範囲を 規定する限界距離 $L_{\max }$ を設定し，概念空間での距離 $l$ が $L_{\max }$ 以下となるエージェント間を連結する。つぎに，一 定の確率でリンクを削除して，ランダムに選択した別の エージェントと連結しなおす。本研究においても，参考 文献 ${ }^{13)}$ に示されている例と同様に, リンクの再連結を行 う確率を $5 \%$ と設定している. また，再連結したリンク の距離は限界距離の $1 / 2$ と設定する.

このときエージェントの概念空間上の再配置は行って おらず，これらのリンクに関しては概念空間上の配置あ るいは距離とエージェント間の関係性が連動していない. ここでは，概念空間での距離 $l$ によってエージェント間 (i,k)の関係性の大きさ $\gamma_{[i, \mathrm{k}]}$ を式(14)のように表現する.

$$
\gamma_{[i, k]}=1-\frac{l_{[i, k]}}{L_{\max }}
$$

これによりエージェント間の関係性の大きさを最大 1.0 で表し, 距離 $l$ に応じて関係性が減少し, 限界距離で は関係性がないことを表すものである。

環境意識に関する周囲のエージェントからの影響の強 さ $w_{[]}(t)$ を, この関係性の大きさ $\gamma_{[i, k]}$ および周囲のエージ エント $k$ の環境意識に基づいて，式(15)により算定する.

$$
w_{[i \mathrm{i}]}(t)=\frac{\sum \gamma_{[\mathrm{i}, \mathrm{k}]} \cdot\left(e c o_{[\mathrm{kk}]}(t)-e c o_{[\mathrm{ij}]}(t)\right)}{\sum \gamma_{[\mathrm{i}, \mathrm{k}]}}
$$

これは周囲のエージェントとの環境意識の差異を関係 性の大きさによって案分し, 関係性のあるすべてのエー ジェントに関しての影響を集積するというものである.

したがって, 関係性の大きいエージェントの環境意識が 高い場合には，そのエージェント自身の環境意識が向上 することになる，一方，関係性の大きいエージェントの 環境意識が低い場合には，そのエージェント自身の環境 意識が減退寸ることも起こり得る．また，他者の環境意 識を正確に把握できると仮定している，ただし，実際に
は他者の環境意識を正確に認識することは容易ではない． 環境意識の相互作用を精緻に記述寸るためには，より精 緻な環境意識調査と分析が必要とされる。ここでは, 簡 単のために，このような仮定を採用することとする.

CEV保有に関する周囲のエージェントからの影響の強 さ $w_{[i]}^{C E V}$ については, この関係性の大きさ $\gamma_{[i, k]}$ および周 囲のエージェントk のCEV保有の有無 $\delta_{[\mathrm{k}]}^{C E V}$ に基づいて, 式(16)のように算定することとする.

$$
w_{[i]}^{C E V}(t)=\frac{\sum r_{[i, \mathrm{k}]} \cdot \delta_{[k]}^{C E V}(t)}{\sum r_{[i, \mathrm{k}]}}
$$

この值は「CEV保有モデル」において, 説明変数「局 所的影響」として設定されることになる.したがって, 関係性の大きいエージェントがCEVを保有している場合 には，そのエージェント自身のCEV保有可能性が向上す ることになる.

以上のように，環境意識と局所的相互作用用を考慮し てCEV普及促進策の検討のためのマルチエージェントシ ミュレーションモデルCEVMASを構成した.

\section{CEV普及状況推計への適用}

これまでに構築したCEVMASを用いて, 仮想社会で のCEV普及状況と環境意識の推移を観測する.

\section{（1）仮想社会の条件設定}

ここでは, CEV 保有意向アンケート調査の対象地域 である徳島都市圈を参考に, 地方都市圈における $\mathrm{CEV}$ 普及状況の推移を観察するための仮想社会を構成する.

エージェントは世帯保有車両のメインドライバーで 個人単位とし，アンケート調査のサンプルを基本エージ ェントとした. 基本エージェントについては, 当該サン プルのそれぞれの質問項目に対する回答に基づいてエー ジェント属性を設定した，基本エージェントを均等に拡 大して複製することで，合計 10000 エージェントを設定 した. これは参考とした徳島市の 25 分の 1 程度のスケ 一ルに相当する.

エージェントの環境意識指標に関しては，「地球環境 問題への関心」の程度に対応して，それぞれの回答の割 合に応じて闇值を規定した。 この闇值に応じてランクご との範囲を確定した後，エージェントごとの「地球環境 問題への関心」の程度に対応して, 一様乱数によりラン ダムに指標を設定した。

推計期間に関しては，1サイクルを1週間単位とし，20 年後（1040週）までの推移を観察することとした．ここ では車両技術革新などは考慮しないこととする．また， 環境意識の更新および局所的相互作用の影響について, 
CEV普及状況への影響をみるために表-8に示すようなケ 一スを設定している.

ここで，環境意識の更新が「なし」のケースでは，式 (13)による更新を実行しないこととする．また，局所的 相互作用の影響が「なし」のケースではCEV保有に関す る周囲のエージェントからの影響がないものとし，「弱 影響」のケースでは式(16)によりを算定することとする。 一方，「強影響」のケースでは，関係するいずれかのエ ージェントがCEVを保有していた場合に，影響の強さを 最大值の「1」とすることとした.

各ケースのシミュレーションでは, 乱数の影響が想定 できるため, 各ケースとも5回の推計を行って，その平 均值の推移を比較するとともに, 各ケース間の最終状態 での推計結果の統計的な有意差についても議論する.

\section{(2) CEV普及状況の推移}

構築したCEVMASを用いて, 仮想社会における CEV 普及状況として, 各ステップでの車両保有状況, 二酸化 炭素排出状況およひ環境意識の推移を観察する.

\section{a) 車両保有状況の推移}

ここでは仮想社会における車両保有状況を観察する. 仮想社会における CEV 保有台数の推移を図-11に示寸. 最終的に CEV 保有割合は 5\%程度となり, アンケート 調査結果とほぼ一致している. 最終状態での推計值につ いて, 各ケース間における平均值の差の検定を行ったと ころ, case-0 と case-3 および case-2 と case-3 を除くすべて の組み合わせで, 有意水準 $5 \%$ で統計的に有意な差があ った. たとえば, case-1 と case-4 の平均值の差の $t$ 值は 5.97 である. このように, case-4 での CEV 保有台数が, 他のケースより大きいことから，局所的相互作用の影響 が強い場合には特にシェアに作用することがわかる.

なお，2013年 3 月時点での実際の電気自動車登録台数 でみると, CEV の保有率は $0.1 \%$ 程度である ${ }^{18)}$. 推計の 起点をアンケート調査時点の 2011 年 10 月として, 推計 結果における 70 週における CEV の保有率（普及率）を 見てみると， $0.05 \%$ 程度と少し過小推計となっている. ただし，実際の電気自動車登録台数には，2011 年 10 月 以前からの保有台数も含まれており, 導入期の推計結果 としては，概ね妥当であるといえる.

つぎにHVおよび低燃費型ガソリン自動車の保有台数 の推移を図-12に示す．最終的にエコカー選択割合 50 - $60 \%$ 程度で安定しており, アンケート調査結果とも 概ね一致している. 最終状態での推計值について, 各ケ 一ス間における平均值の差の検定を行ったところ, case0 と case-1およびcase-2 と case-3 と case-4の組み合わせでは, 統計的に有意な差がみられず，それらを除く組み合わせ で，有意水準 $5 \%$ で統計的に有意な差があった．このよ うに，最終的なエコカー普及状況は環境意識の更新の有
表-8 ケース設定

\begin{tabular}{|c|l|c|c|}
\hline \multicolumn{2}{|c|}{ ケース名称 } & $\begin{array}{c}\text { 環境意識 } \\
\text { の更新 }\end{array}$ & $\begin{array}{c}\text { 局所的相互 } \\
\text { 作用の影響 }\end{array}$ \\
\hline case-0 & ぶース & なし & なし \\
\hline case-1 & 弱影響 & なし & 弱影響 \\
\hline case-2 & 意識 & あり & なし \\
\hline case-3 & 意識+弱影響 & あり & 弱影響 \\
\hline case-4 & 意識+強影響 & あり & 強影響 \\
\hline
\end{tabular}

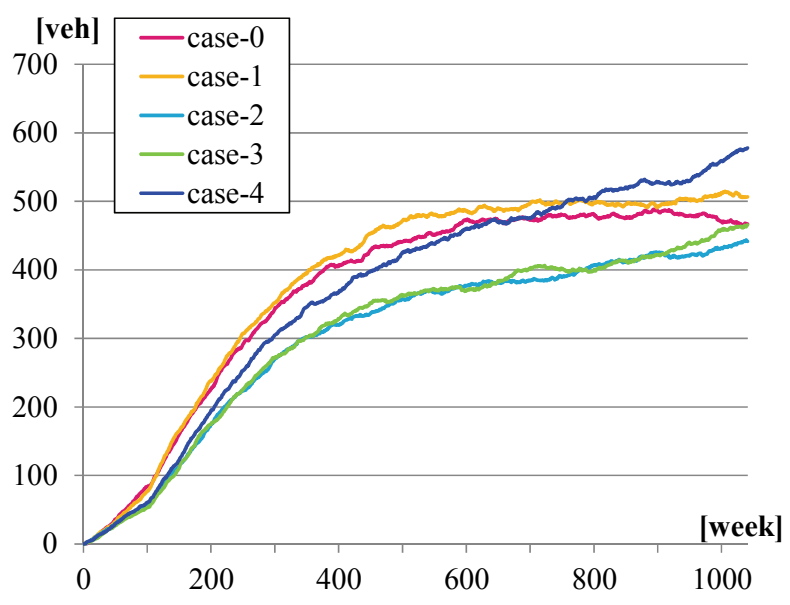

図-11 CEV保有台数の推移

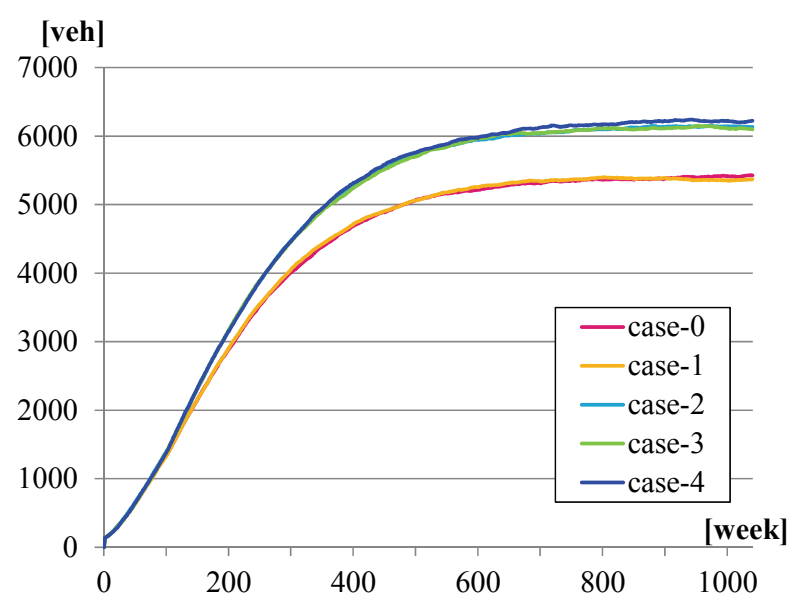

図-12 HVおよび低然費型ガソリン自動車の保有台数の推移

無により大きな影響を受けることがわかる.

\section{b) 二酸化炭素排出状況の推移}

エージェントの保有車両の利用にともなう二酸化炭素 排出量の推移を図-13 に示す. CEV および低燃費型自動 車の普及にともなって，3～10 年までは排出削減目標を 達成できている，最終的には二酸化炭素排出量は 30\% 40\%の削減が見込まれる.これは主に HVおよび低 燃費型ガソリン自動車の普及の影響が大きいことと考え られる。しかしながら，CEV および低燃費型自動車の 普及が停滞する 10 年後以降に排出削減も停滞寸る傾向 がみられる。これは，現状の CEV および低燃費型自動 車の普及による二酸化炭素排出削減の限界を示寸ものと 
考えられる. このため, 中長期的には, 車両の技術革新 を含む CEV 普及促進へのさらなる対策が求められる.

また，最終状態での推計值について，各ケース間にお ける平均值の差の検定を行ったところ, エコカー普及状 況と同様に，環境意識の更新の有無により，有意水準 5\%で統計的に有意な差があった.

つぎに二酸化炭素排出削減平均費用の推移を図-14に 示寸．排出削減目標を達成できない 10 年目以降に関して, オフセット費用は増大していくことがわかる。しかしな がら，その影響によりCEVおよびエコカーの保有に転換 するエージェントはあまり多くはみられない，

\section{c) 環境意識の推移}

ここでは，エージェントの環境意識の推移に関して分 析する. 環境意識指標ecoの社会全体での平均值の推移 を図-15に示す，環境意識の更新のあるケースではす心゙ て，一貫して環境意識の向上がみられる。このように, 構築した環境意識モデルでは環境意識には正のフィード バックが働く構造になっている. しかしながら，CEVお よび低然費型自動車の普及は 10 年目以降では停滞するこ とから，社会全体での環境意識が向上していくだけでは， CEVおよび低燃費型自動車の普及にも限界があることが わかる.

\section{5. おわりに}

本研究では, クリーンエネルギー車両 CEV の普及過 程に関して，環境意識と社会的同調の局所的相互作用を 考慮して, マルチエージェントシミュレーションモデル CEVMAS を構築し，CEV の普及状況と環境意識の推移 を推計した. 本研究の成果は, 以下のように整理できる. [1] マルチェージェントシミュレーションモデル CEVMAS として，「車種決定プロセス」および「排 出量算定プロセス」に加え,「時間進行管理プロセ ス」を含めた構成を提案した. CEV 保有に関わる要 因のつながりが明確になるとともに，環境意識の 「局所的相互作用」だけでなく，CEV 保有の社会的 同調性としての「局所的相互作用」の効果がフィー ドバックされるフレームを構成できた.

[2] CEV 保有に関わる車種決定に関して 2 段階の意思決 定構造を想定し, 選別段階として CEV 保有意向モデ ル，選択段階として保有可能性有無別の車種選択モ デルを構築した．CEV 保有意向モデルでは，環境意 識（地球環境問題への関心）および親近者の CEV 保 有（局所的影響）が CEV 保有可能性に関わることを 統計的に検証した。 また，車種選択モデルでは，環 境意識（自動車排出削減の必要性の認識）が車種選 択に関わることを示した.

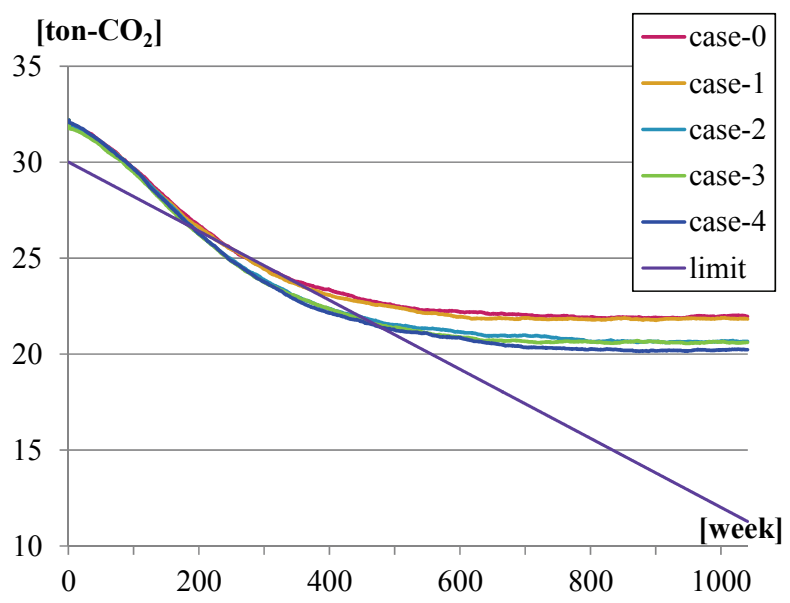

図-13 二酸化炭素排出量の推移

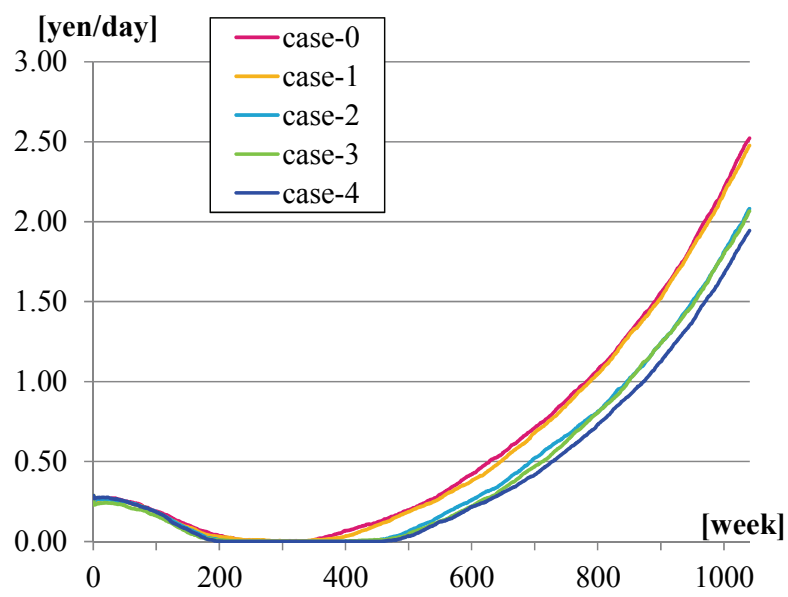

図-14 二酸化炭素排出削減平均費用の推移

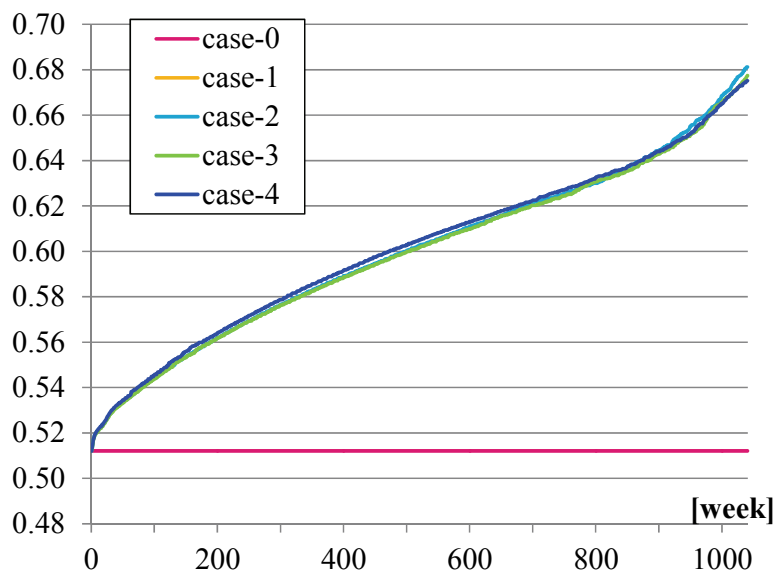

図-15 環境意識指標(平均值) の推移

[3] 車種決定プロセスにおいて，CEV 保有意向に関わる 環境意識および親近者の CEV 保有における局所的相 互作用を具体的に記述した。また，エージェント間 の関係性の表現に small world network を適用寸ることで, 局所的相互作用が社会的ネットワークを通して, 社 会全体に拡散する過程を表現できた. 
[4] 排出量算定プロセスにおいて, 燃費と走行距離から 二酸化炭素排出量を算定するモデルを組み込み，社 会全体の二酸化炭素排出量をフィードバックする構 造を構築できた。.また，加速八ザードモデルの枠組 を適用し，保有車種とメインドライバー属性および 走行距離を要因として, 保有車両の燃費をワイブル 分布で表現した.

[5] 時間進行管理プロセスにおいて，ワイブル分布によ る加速八ザードモデルの枠組を適用し，車両購入時 期決定モデルを構成した。 世帯収入および家族構成 による車両更新期間の差異を統計的に検証できた.

[6] CEV 普及状況の推計結果から, 普及促進策の追加的 な措置あるいは車両性能の技術的革新がない場合に は，20 年後においても CEV 保有割合は $5 \%$ 程度に留 まる可能性が示された，一方，HV を含む低燃費型車 両は 50-60\%程度の普及可能性が見込まれる。

[7] 環境意識の更新の有無により, 低燃費型車両の普及 状況に有意な差がみられ，その結果として二酸化炭 素排出量に有意な差がみられる推計が得られた。ま た，社会全体での環境意識が向上していくだけでは， CEV および低燃費型自動車の普及にも限界があるこ とを示した.

今後の課題としては, (1) 環境意識の更新に関して, 実証的なアプローチが必要である．また，各種の普及促 進策の効果の分析 ${ }^{199}$ 参考として，(2) 普及促進策の効 果を表現できる CEV 保有モデルを構築するとともに, MA シミュレーションモデルに統合して拡張し, 各種の 普及促進策の影響を評価できるように構成することが挙 げられる。

謝辞 : 本研究は, 科学研究費助成事業（学術研究助成基 金助成金）基盤研究(C) 25420549の研究成果の一部です. また, 本研究で利用したアンケート調查結果の一部は, 日本交通政策研究会における2011年度のプロジェクト 「環境負荷を考慮した都市交通政策の定量評価に関する 研究」で実施されたものである.ここに記し，感謝の意 を表する次第です。

\section{参考文献}

1) 交通工学研究会 EST 普及研究グループ編著: 地球温 暖化防止に向けた都市交通一対策効果算出法と EST 先進都市に学ぶー, 交通工学研究会, 2009.

2) 照井伸彦, 佐藤忠彦: 現代マーケティングリサーチ, 有斐閣, 2013.

3) Bass, F. M. : A New Product Growth for Model Consumer Durables, Management Science, Vol. 15, No. 5, pp. 215227, 1969.
4) Lee, J., Cho, Y., Lee, J. and Lee, C. : Forecasting future demand for large-screen television sets using conjoint analysis with diffusion model, Technological Forecasting and Social Change, Vol. 73, pp. 362-376, 2006.

5) 松本光崇, 近藤伸亮 : 産業技術の社会受容一既存の 3 モデルを統合した環境製品普及評価モデルの構築, 構成学, Vol.2, No. 1, pp. 23-31, 2009.

6) 大野宏司：市場データとシミュレーションによるエ コカーの普及予測, 日本シミュレーション学会論文 誌, Vol.2, No. 2, pp. 82-91, 2010.

7) 松原司, 桑野将司, 塚井誠人：選別・選択段階にお ける他者への同調効果を考慮した電気自動車普及要 因に関する分析, 土木学会論文集 D3, Vol.68, No.5, pp. 691-699, 2012.

8) 井庭崇, 竹中平蔵, 武藤佳恭 : 人工市場アプローチ による家庭用 VTR の規格競争シミュレーション，情 報処理学会論文誌：数理モデル化と応用, Vol.42, No.SIG14 (TOM5), pp.73-89, 2001.

9) 川村秀憲, 大内東 : ネットワーク外部性の働く製品 市場のモデル化とプレゼント戦略の評価, 日本オペ レーションズ・リサーチ学会和文論文誌, Vol. 48, pp.48-65, 2005.

10) 今井陽平, 奥嶋政嗣, 近藤光男 : 通勤交通手段転換 に関わる環境意識とその社会的相互作用の構造分析, 土木学会論文集 D3, Vol.68, No.5, pp. 607-614, 2012.

11) Okushima, M. and Akiyama, T.: Multi-agent transport simulation model for eco-commuting promotion planning, Journal of Advanced Computational Intelligence \& Intelligent Informatics, Vol.15, No.7, pp.911-918, 2011.

12) 奥嶋政嗣, 秋山孝正 : マルチェージェントシミュレ ーションによるエコ通勤促進策の影響分析, 土木学 会論文集 D3, Vol.68, No.5, pp.625-634, 2012.

13) Watts, D. J. and Strogatz, S. H.: Collective dynamics of 'small-world' network, Nature, Vol.393, pp.440-442, 1998.

14) 石井亜也加，奥嶋政嗣 : 現状保有車両を考慮したクリー ンエネルギー車両保有可能性モデルの構築, 土木計画学 研究·講演集, Vol.46, 5pages, 2012.

15）森川高行, 北村隆一：交通行動の分析とモデリング, 技 報堂出版, 2002.

16）環境省：（家庭からの二酸化炭素排出量算定用）排出係 数一覧, 2006 .

17) 西條辰義, 新澤秀則, 明日香壽川, 平石尹彦, 戒能 一成, 鮎川ゆりか, 本郷尚 : 地球温暖化の経済学, 大阪大学出版会, 2009.

18) 次世代自動車振興センター：統計／電気自動車等保有台 数 (推計值) (http://www.cev-pc.or.jp/tokei/hanbail.html),2014 年 7 月 7 日参照.

19) 石井亜也加, 奥嶋政嗣 : クリーンエネルギー車両保有に 関寸る普及促進策の効果分析, 土木計画学研究·講演集, Vol.48, 5pages, 2013.

(2014.2.28 受付) 


\section{SIMULATION FOR PROMOTION PLANNING OF CLEAN ENERGY VEHICLE CONSIDERING WITH SOCIAL INTERACTION}

\section{Masashi OKUSHIMA and Ayaka ISHII}

The global warming problem by greenhouse gas emission has become more serious. Also in the transportation section, clean energy vehicles such as EV or PHV should be promoted as well as the modal shift, since CEV can be moved with the low load to the global environment. However, it is pointed out that the social interaction affects the promotion of CEV. Therefore, the multi agent simulation system for promotion planning of CEV is developed with local interaction process as social conformity in the present study. Intention of holding $\mathrm{CEV}$ is described with the database of the questionnaire survey about purchasing Eco-vehicles. On the other hand, the social network of the artificial society is described as the small world network model. According to some scenario, the promotion processes of CEV in the artificial society are observed with the proposed MAS system. Finally, it can be concluded that the proposed multi agent simulation with local interaction is useful for promotion planning of $\mathrm{CEV}$. 